\title{
CROWN ESTATE DEVOLUTION
}

\author{
Aileen McHarg ${ }^{*}$
}

\section{A. INTRODUCTION}

One of the Smith Commission's more significant recommendations was that responsibility for managing the Crown Estate in Scotland, and the revenue generated from it, should be transferred to the Scottish Parliament. ${ }^{1}$ The Crown Estate is currently managed on a UK-wide basis by the Crown Estate Commissioners under the Crown Estate Act 1961 ("CEA"). Its origins date back to 1760, when George III surrendered the revenues from Crown lands to Parliament in return for support via the Civil List, an arrangement confirmed by each subsequent Monarch. Today, the Crown Estate consists of a mixture of hereditary Crown property rights, more recent rights vested in the Crown by statute, and modern property acquisitions. It does not comprise the entirety of Crown property rights, nor is it the personal property of the Sovereign. It is, in effect, a publicly-owned property business, the revenues from which accrue to the UK Treasury.

The Crown Estate's holdings in Scotland are legally and historically distinct, having not been surrendered until 1830, and brought under common management by the Crown Lands Act 1833. They include: a small amount of urban and commercial property; several large rural estates; rights to salmon fishing, gold, silver and other reserved minerals; internal waterways; and - most significantly - the so-called "marine estate". The latter includes around $50 \%$ of the foreshore, and almost all the seabed within Scotland's territorial waters, including aquaculture and mooring rights. The Crown Estate also exercises rights over the seabed and subsoil in the UK continental shelf, including minerals other than coal and hydrocarbons, ${ }^{2}$ and has been granted rights over offshore renewable energy production ${ }^{3}$ and gas storage. ${ }^{4}$ In 2013/14, the Crown Estate's Scottish holdings were worth f267 million and generated $£ 13.6$ million gross revenue. ${ }^{5}$

Securing agreement to devolve the Crown Estate was a significant victory for the Scottish Government. In 2009, the Calman Commission had rejected its argument for devolution, ${ }^{6}$ and an attempt to amend what became the Scotland Act 2012 was also unsuccessful. ${ }^{7}$ However, the case for devolution was subsequently strengthened by the publication of several reports critical of the operation of the Crown Estate in Scotland. ${ }^{8}$ Particularly important was the highly effective campaign by Scotland's islands councils during the independence referendum arguing for control over the

\footnotetext{
* Professor of Public Law, University of Strathclyde.

${ }^{1}$ Report of the Smith Commission for Further Devolution of Powers to the Scottish Parliament (2014) para 32.

${ }^{2}$ Continental Shelf Act $1964 \mathrm{~s} 1$.

${ }^{3}$ Energy Act 2004 s 84.

${ }^{4}$ Energy Act $2008 \mathrm{~s} 1$.

${ }^{5}$ The Crown Estate, Scotland Report 2014, available at: http://www.thecrownestate.co.uk/media/300060/scotland-report-2014.pdf

${ }^{6}$ Commission on Scottish Devolution, Serving Scotland Better: Scotland and the United Kingdom in the $21^{\text {st }}$ Century (2009) paras $5.110-5.122$.

${ }^{7}$ Marine Scotland, Scotland Bill - Crown Estate (Scottish Government, 2011).

${ }^{8}$ House of Commons Scottish Affairs Committee, The Crown Estate in Scotland, $7^{\text {th }}$ Report 2010-12, HC 1117; The Crown Estate in Scotland - Follow Up, $5^{\text {th }}$ Report 2013-14, HC 889; Land Reform Review Group, The Land of Scotland and the Common Good (2014) ch 11.
} 
marine estate, ${ }^{9}$ something which required the prior transfer of control to the Scottish Parliament. Indeed, the Smith Commission specifically recommended that there should be further devolution to council level following devolution to Holyrood. ${ }^{10}$

However, when the UK Government published its draft clauses in January $2015,^{11}$ the complex approach taken to Crown Estate devolution caused some consternation, with the Scottish Government alleging that it did not fulfil the spirit of Smith's recommendation. ${ }^{12}$ Nevertheless, despite attempts by the Scottish Government and others to secure changes, the clause survived largely intact, with only minor, clarificatory amendments made by the UK Government. Some aspects of what became section 36 of the Scotland Act 2016 came into force immediately upon Royal Assent, ${ }^{13}$ but completion of the devolution process depends upon agreement between the Scottish and UK Governments of a transfer scheme and a Memorandum of Understanding (MoU), neither of which had been concluded at the time of writing.

The remainder of this note briefly considers the arguments for and against Crown Estate devolution, the Scotland Act provisions, and the likely future of the Crown Estate in Scotland. It argues that, while the case for devolution may have been won in principle, the objections to it clearly continued to shape the UK Government's approach to devolution, and will constrain the exercise of the devolved powers in practice.

\section{B. THE CASE FOR DEVOLUTION}

The case for devolution of the Crown Estate is essentially twofold. ${ }^{14}$ First, there is no clear rationale for the current division between reserved and devolved competences. For one thing, some Crown property is already devolved, and the Scottish Parliament also controls the definition of Crown property rights at common law. More importantly, most policy responsibilities relevant to the administration of the Crown Estate in Scotland are also devolved. In the energy field, for instance, the Crown Estate has an important planning role in relation to the siting of renewable energy and storage installations, as well as cables and pipelines, through seabed leasing. However, the Scottish Government has the lead role on promotion of renewables, and also controls marine licensing ${ }^{15}$ and some energy consents. ${ }^{16}$ This division of responsibilities is cumbersome, costly and potentially confusing for developers, and there is a risk of conflict between the leasing and regulatory regimes.

\footnotetext{
${ }^{9}$ Our Islands - Our Future, Constitutional Change in Scotland - Opportunities for Islands Areas (2013), available at: http://www.shetland.gov.uk/OIOF/documents/ourislands-ourfuture-JointPositionStatement17june2013.pdf.

${ }^{10}$ Smith Commission, $\mathrm{n} 1$, at para 33.

${ }^{11}$ HM Government, Scotland in the United Kingdom: An Enduring Settlement, Cm 8990 (2015).

12 See, eg, Scottish Government Press Release, 'Crown Estate Devolution', 17 June 2015.

${ }^{13} \mathrm{~S} 36(1),(5),(6)$ and (9) to (12).

${ }^{14}$ See Scottish Government, Administration of the Crown Estate in Scotland - Case for Change (2011); Marine Scotland, $\mathrm{n} 7$; and references in $\mathrm{n} 8$ above.

${ }^{15}$ Marine licensing within Scottish territorial waters is governed by the Marine (Scotland) Act 2010; outwith territorial waters it is governed by the Marine and Coastal Access Act 2009, but is executively devolved to the Scottish Ministers.

${ }^{16}$ Consents to offshore generating stations and power lines under the Electricity Act 1989 ss 36 and 37 are executively devolved. Licensing and permitting of energy storage facilities under the Energy Act 2008 Pt 1 is shared between the UK and Scottish Governments. Pipeline consents are governed by the Petroleum Act 1998 Pt 3, and are reserved.
} 
Secondly, there is long-standing dissatisfaction with the operation of the Crown Estate in Scotland. Its statutory duty is to maintain the Crown Estate "as an estate in land ..., to maintain and enhance its value and the return obtained from it, but with due regard to the requirements of good management." ${ }^{17}$ This is interpreted to mean that it should act as a commercial property business, aiming to maximise revenues, subject to requirements of integrity and good stewardship, ${ }^{18}$ but prohibited from taking account of wider policy objectives. This commercial rather than governmental conception of its role leads, critics claim, to a lack of transparency, accountability and public participation in its decision-making, and a lack of communication and engagement with key stakeholders and local communities. Here, the case for devolution ties into the broader land reform agenda, with the desire to secure greater community control over land use and revenues, and to ensure that land is used sustainably for the common good.

\section{THE CASE AGAINST DEVOLUTION}

Objections to devolution centre around the desire to maintain the integrity of the Crown Estate, and the need to protect reserved policy interests. Regarding the former, certain Conservative MPs argued during debates on the Scotland Bill that devolution was inappropriate because, due to the unity of the Scots and English Crowns, the Crown Estate is indivisible. ${ }^{19}$ This argument is legally and historically inaccurate, and ignores the contemporary reality that the particular mix of Crown assets encompassed within the Crown Estate is essentially haphazard. It is also worth stressing that devolution of the management of the Crown estate does not alter the ownership of the assets themselves, though this begs the question why it is necessary to maintain a Crown property portfolio at all. ${ }^{20}$ While, calculation of the Sovereign Grant is pegged to Crown Estate revenues, ${ }^{21}$ this is merely a proxy rather than an actual cash transfer, and is an arrangement of no great antiquity.

The second concern is that a devolved Crown Estate might, though its land-use decisions or by charging excessive rents, compromise UK-wide critical national infrastructure in areas such as defence, security, energy and telecommunications, or impose undue costs on taxpayers and consumers elsewhere in the UK. This is more justifiable, though it is questionable whether these interests are any safer under the current arrangement whereby the Crown Estate exercises its monopoly powers purely for commercial gain. While ministers can give directions to the Commissioners, ${ }^{22}$ these powers are regarded as exceptional and have never been used; something the Treasury Select Committee strongly criticised in 2010. ${ }^{23}$ Nevertheless, the Smith Commission recommended that the Scottish and UK Governments should agree an MoU to ensure that devolution is not detrimental to critical infrastructure, and to safeguard the defence and security importance of the Crown Estate's foreshore and seabed assets. ${ }^{24}$

D. THE SCOTLAND ACT 2016

\footnotetext{
${ }^{17}$ CEA s $1(3)$.

${ }^{18}$ See http://www.thecrownestate.co.uk/who-we-are/our-values/.

${ }^{19}$ See Jacob Rees-Mogg and Dominic Grieve, HC Deb, 6 June 2015, cols 77 - 85, 90 - 93.

${ }^{20}$ This is not to deny the strong case for maintaining certain assets, such as the seabed, in public ownership.

${ }^{21}$ Sovereign Grant Act 2011.

${ }^{22}$ Crown Estate Act 1961 s 4.

${ }^{23}$ House of Commons Treasury Committee, The Management of the Crown Estate, $8^{\text {th }}$ Report $2009-10$, HC

325 , paras $118-122$.

${ }^{24}$ Smith Commission, $n 1$, at para 34.
} 
Section 36 does three main things. First, subsection (1) inserts a new section 90B into the Scotland Act 1998 ("SA 1998"), which enables the Treasury, with the Scottish Ministers' consent, ${ }^{25}$ to make a scheme ("the transfer scheme") transferring all the Crown Estate Commissioners' existing Scottish functions to the Scottish Ministers or a person nominated by them ("the transferee"). As an interim measure, subsection (7) applies the CEA to the transferee, but subject to the power in subsections (8) to (12) for the Scottish Ministers to make provision by Order in Council in advance of the transfer for the exercise by the transferee of its functions, including establishing a new body. Second, subsections (2) to (4) amend Schedule 5 Part 1 of the SA 1998 to limit the reservation of the Crown Estate to "the property, rights and interests under the management of the Crown Estate Commissioners", thereby enabling the Scottish Parliament to legislate for the future management of the transferred functions. Third, subsection (13) amends the Civil List Act 1952 to provide for payment of Scottish Crown Estate revenues into the Scottish Consolidated Fund.

The transfer scheme was the most controversial aspect of section 36. It was justified as being necessary to transfer executive as well as legislative powers over the Crown Estate ${ }^{26}$ and to clarify the precise rights and liabilities being transferred. ${ }^{27}$ However, while establishing separate administrative arrangements for the Scottish assets immediately upon devolution might be convenient, it clearly was not necessary. A simple amendment of Schedule 5 Part 1 of the SA 1998 would have automatically devolved ministerial functions over the Crown Estate Commissioners ${ }^{28}$ and enabled the Scottish Parliament to decide how and by whom their Scottish responsibilities should be exercised in future.

The transfer scheme model also has some important implications. First, not all Crown Estate assets in Scotland will be included in the scheme. The lucrative Fort Kinnaird shopping centre, which is owned by an English Limited Partnership in which the Crown Estate has an interest, is excluded. ${ }^{29}$ Moreover, the Crown Estate Commissioners are still permitted to make commercial investments in Scotland, and the management of such assets will remain reserved. ${ }^{30}$

Secondly, section 90B constrains the future management of the transferred assets. They must continue to be managed on behalf of the Crown and must be maintained as an estate (or estates) in land. ${ }^{31}$ While the new manager can alter the pool of assets within the transferred estate, a Crown property portfolio must continue to exist in perpetuity, ${ }^{32}$ and Holyrood will be unable to alter these requirements. ${ }^{33}$ Further, the transfer scheme must include such provision as the Treasury consider "necessary or expedient" (emphasis added) to protect defence and national security, telecommunications and energy infrastructure, and the interests of electricity consumers. ${ }^{34}$ The draft transfer scheme published in October 2015 contained extremely detailed powers of intervention for the UK Government, going far beyond the directive powers in the CEA, and

\footnotetext{
${ }^{25}$ S 90B(17) SA 1998.

${ }^{26}$ David Mundell, HC Deb, 6 June 2015, col 117.

${ }^{27} \mathrm{HM}$ Government, $\mathrm{n}$ 11, at para 5.5.4.

${ }^{28}$ See Sch 5, Pt, para 2(1)(b) SA 1998.

${ }^{29} \mathrm{~S} 90 \mathrm{~B}(3) \mathrm{SA} 1998$.

${ }^{30} \mathrm{HM}$ Government, $\mathrm{n} 11$, at para 5.5.2.

${ }^{31}$ S 90B (5) and (8) SA 1998

32 Lord Dunlop, HL Deb, 19 January 2016, col 669.

${ }^{33}$ S 36(4) SA 2016.

${ }^{34}$ S 90B(12) SA 1998.
} 
overlapping substantially with the draft MoU. ${ }^{35}$ Whether these will survive in the final scheme is unclear, but the important point again is that the Scottish Parliament will be unable to alter them. ${ }^{36}$ It will also be unable to alter the recipient of Crown Estate revenues, as the "hereditary revenues of the Crown" remain reserved. ${ }^{37}$

In view of these constraints, a final problem with the transfer scheme model is its lack of transparency and appropriate scrutiny. The detailed provisions are for negotiation between the Scottish and UK Governments, and while the implementing statutory instrument will be subject to affirmative resolution in both Houses of Parliament, ${ }^{38}$ there is no role for the Scottish Parliament in its enactment or amendment.

\section{E. THE FUTURE OF THE CROWN ESTATE IN SCOTLAND}

The future of the Crown Estate in Scotland is, at the time of writing, uncertain. The Scottish Government is proposing to establish, via Order in Council, an independent statutory corporation, to be named Crown Estate Scotland (Interim Management), has stated that a single entity will to manage the assets in the short term, and = whether the Scottish Ministers or a new or existing independent body is not clear-but-will consult further in due course over new primary legislation to establish longer-term arrangements. ${ }^{3940}$ Eventual rReforms are likely to include ensuring that management of the transferred assets "is subject to broader objectives, including community benefit and community development as well as revenue raising," ${ }^{41}$ plus giving islands and other coastal councils a role in managing marine assets and ensuring that they benefit from the revenue from marine activities within territorial waters. ${ }^{42}$ There remains a political consensus in favour of a role for local authorities, ${ }^{43}$ although proposed amendments to the Scotland Bill to force such "double devolution" were resisted by both the UK and Scottish Governments. Nevertheless, the constraints imposed by section 36 may limit the radicalism of any potential changes in this regard.

\footnotetext{
${ }^{35}$ Available at: http://www.parliament.scot/Papers 20151119.pdf.

${ }^{36}$ S 90B(13) SA 1998: "Any transfer by the scheme is subject to any provision under subsection (12)"; and the Parliament has no competence to amend s90B.

37 Sch 5, Pt 1, para 3(3)(a) SA 1998.

38 S 36(5) SA 2016.

39 Marine Scotland, Crown Estate - Consultation on Proposals for Establishing the Interim Body to Manage the Crown Estate Assets in Scotland Post-Devolution (June 2016), available at: https://consult.scotland.gov.uk/crown-estate-strategy-unit/manage-the-crown-estate-assets.

${ }^{40}$ Scottish Government, Interim Management of Crown Estate Assets (SAGCE 4/2016), available at: http://www.gov.scot/Topics/marine/seamanagement/TCE/AdvisoryGroup/13012016Papers.

${ }^{41}$ Scottish Government, The Crown Estate - Current Scottish Government Policy (SAGCE 6/2015), available at: http://www.gov.scot/Topics/marine/seamanagement/TCE/AdvisoryGroup/SeptMins.

42 Ibid.

${ }^{43}$ Other interest groups may, however, be opposed - see Devolution (Further Powers) Committee, New Powers for Scotland - An Interim Report on the Smith Commission and the UK Government's Proposals, SP Paper 720, $3^{\text {rd }}$ Report, Session 4 (2015) para 387.
} 